\title{
超低抵抗值を有する電極用複合材料の開発
}

\author{
吕 明哲* . 足高 善也** \\ 多田 裕志 $*$. 井上 英俊*
}

Journal of The Japan Institute of Light Metals, Vol. 62, No. 3 (2012), 115-121

\section{Development of super-low resistance electrodes of a capacitor}

\author{
Akinori RO*, Zenya ASHITAKA** \\ Hiroshi TADA* and Hidetoshi INOUE*
}

Keywords: aluminum, carbon, composite, capacitor, electrode

\section{1.はじめに}

アルミニウム䇴は, その優れた特徵を活かして食品医薬品 包材，建築資材，電子部品等多くの用途に使用されてきた。

特に近年では家電製品, 携帯機器のめまぐるしい発達に伴 い, 使用される電子部品は，より高性能および小型化が求め られ，性能の向上に日進月歩で開発が進められている。中で も, パーソナルコンピュータ, 液晶テレビ, LED照明機器 などでは高性能はもちろんのこと, 長寿命化が性能の一つと して求められてきている。その電気製品の寿命を決定する電 子部品の 1 つしてアルミニウム電解コンデンサが挙げられ る。アルミニウム電解コンデンサに使われるアルミニウム箔 は, 酸を使った化学反応あるいは電気化学反応によりアルミ ニウム箔の表面を溶解し, 箔の表面積を拡大するエッチング 法が施されてきた。エッチング技術の向上に伴ってアルミニ ウム電解コンデンサの静電容量は向上してきたが, エッチン グ法では䇴の厚さや引張強さの制約から表面積の拡大に限界 があり, これ以上の表面積の拡大は難しくなってきている。

当社では以前からアルミニウム箔の加熱処理技術を検討し ており，アルミニウム箔を炭化水素雲囲気の中で高温加熱す ると䇴表面にアルミニウムカーバイド (以下 $\mathrm{Al}_{4} \mathrm{C}_{3}$ と記す) を主成分とする結晶化合物が発生することを発見した。この 技術を応用することでアルミニウム箔の表面にカーボン粒子 を固着した複合材料（商品名：トーヤルカーボ®）を開発す ることに成功した1）。

一般的にアルミニウム䈃の表面には，自然酸化皮膜が存在 し，電池やコンデンサに使われる際にはその酸化物は電気抵 抗を増加させてしまう。そこで古くから簡易的にアルミニウ ム箔の電気抵抗を下げるためにカーボン粒子を箔表面に固定 する処方が施されている。その方法はカーボン粒子とその固 定用に有機高分子いわゆる有機バインダを混ぜてコートする 方法である。しかし，この方法では電気抵抗をある程度下げ
ることができるものの, カーボン粒子の固定力を高めるため にバインダの添加量を増やすと電気抵抗が高くなる。逆に, 電気抵抗を下げるために添加量を少なくすると，有機バイン ダが温度の影響を受け劣化し, 長期間使用するとカーボン粒 子が剥離する心配がある。

これに対し当社の固定方法は，非常に高い接着力を示すと 同時にカーボン粒子の固定に有機成分を含まないので，熱に 対する安定性が高い。

一方，これまでアルミニウム電解コンデンサは，電解液を 使ったものが主流であったが，導電性高分子材料を電解液の 代替として用いた機能性固体高分子コンデンサが開発され た。電解液を導電性高分子に変更したことで電気抵抗の低 減，さらに固体になったことで電解液の蒸発がなくコンデン サの耐熱性および寿命が格段に向上した。

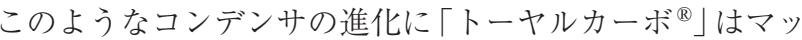
チングし, 機能性固体高分子コンデンサの陰極として使用す ると優れた電気特性を引出すことから，採用されることと なった。

特に,パーソナルコンピュータの分野においては, ESR（等価直列抵抗）の低いコンデンサが求められ，「トー ヤルカーボ®」を使ったコンデンサは，進化し続けるパーソ ナルコンピュータのCPU (中央処理装置) の周辺にはなく てはならない存在となってきた。この広がりはパーソナルコ ンピュータの分野だけには留まらず，最近では液晶テレビや LED照明機器, 自動車においてはカーナビゲーションシス テムや電子制御部のような用途にまで広がってきている。

\section{2.「トーヤルカーボ®」}

\section{1「トーヤルカーボ®」の製造工程}

「トーヤルカーボ®」の製造工程を図1に示す。まず所定の 厚みまで圧延したアルミニウム箔の上に, 厚さ $1 \mu \mathrm{m} /$ 片面に なるように調整したカーボン粒子をコートし，炭化水素雲囲

*東洋アルミニウム株コアテクノロジーセンター研究開発室（％581-0082 大阪府八尾市相生町 4-8-1)。 Research and Development Department, Core Technology Center, Toyo Aluminium K.K. (4-8-1 Aioi-cho, Yao-shi, Osaka 581-0082).

**東洋アルミニウム(株新機能材技術部（八尾市）。New Functional Material Technology Department, Toyo Aluminium K.K. (Yao-shi, Osaka). 受付日：平成23年11月30日＼cjkstart受理日：平成23年12月27日 

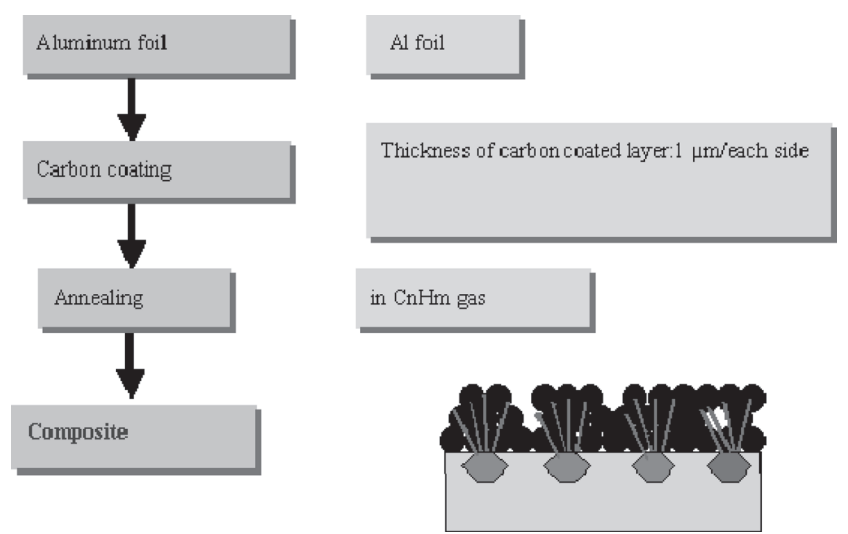

図1「トーヤルカーボ®」の製造工程

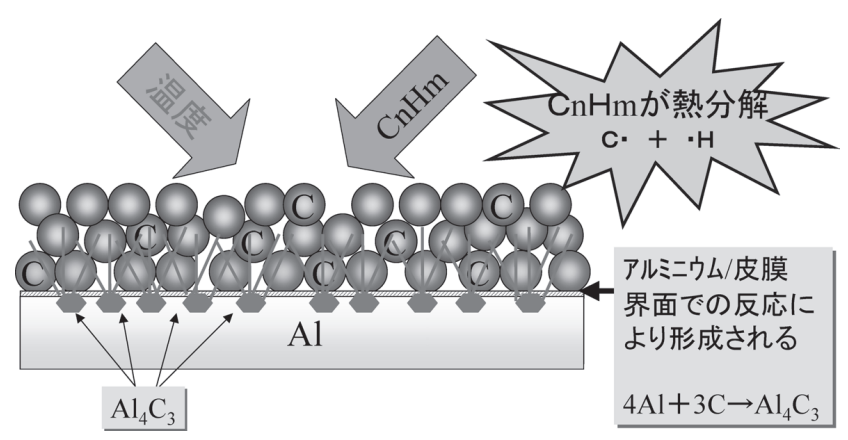

図2 $\mathrm{Al}_{4} \mathrm{C}_{3}$ の形成のメカニズム

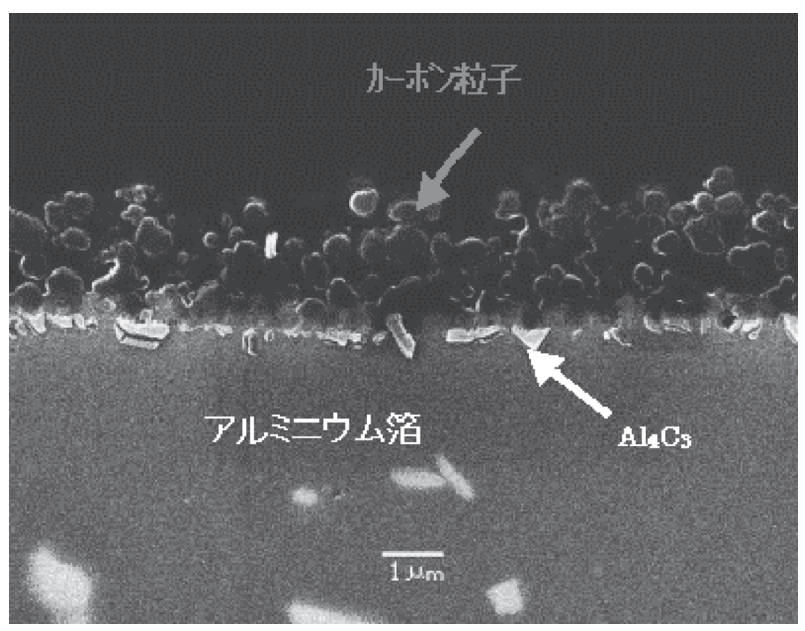

図3「トーヤルカーボ ${ }^{\circledR} 」 の$ 断面観察

気の中で $873 \mathrm{~K}$ 以上の温度で保持することで $\mathrm{Al}_{4} \mathrm{C}_{3}$ が生成し, アルミニウム箔にカーボン粒子を固着することができる。

この固着するメカニズムを図 2 に示す。炭化水素を高温で 加熱すると炭素と水素の結合が切れ, 熱分解が起こる。この ときにラジカル状態となった炭素がアルミニウム箔表面に形 成された酸化皮膜の界面にあるアルミニウムと反応し, $\mathrm{Al}_{4} \mathrm{C}_{3}$ の板状結晶を形成し, さらにウイスカの成長を促すも のと考えられる。

完成した「トーヤルカーボ ${ }^{\circledR} 」 の$ 断面を走査型電子顕微 鏡（以下 SEMと記す）で観察したものを図3に示す。写真 からもわかるようにアルミニウム箔とカーボン粒子の界面部 に $\mathrm{Al}_{4} \mathrm{C}_{3}$ 結晶化合物が存在することがわかる。また, アルミ

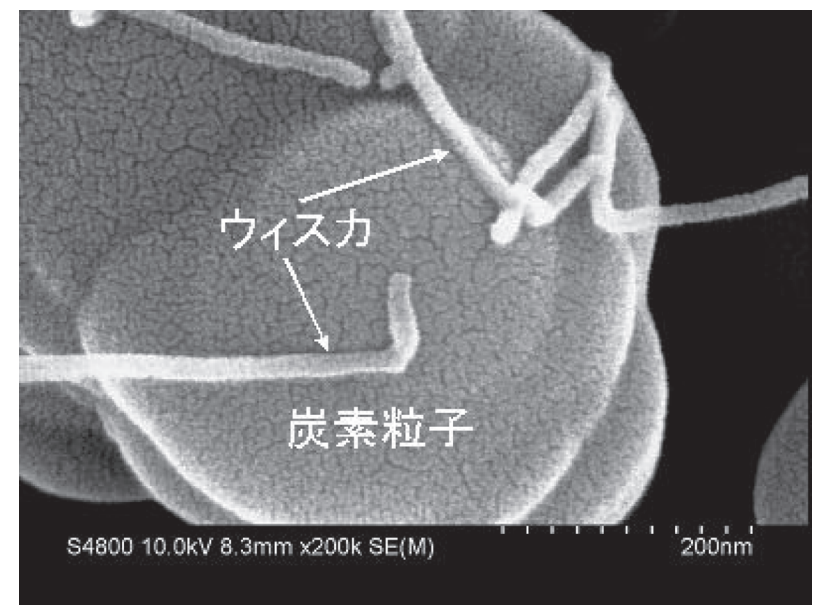

図4 炭素粒子を捉えているウイスカ

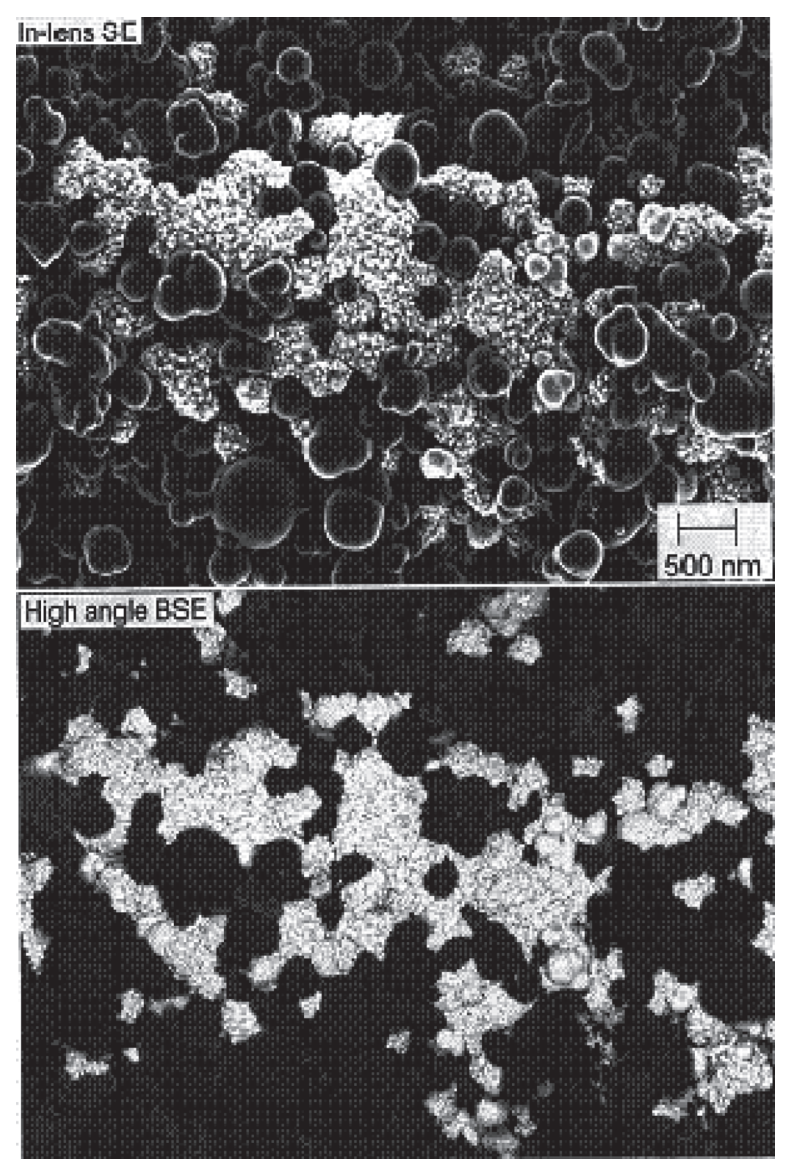

図5アルミニウム箔表面に発生した $\mathrm{Al}_{4} \mathrm{C}_{3}$ 結晶化物の 分布状況 (上：二次電子像, 下：反射電子像)

ニウム箔表層から成長した $\mathrm{Al}_{4} \mathrm{C}_{3}$ 結晶化合物のウイスカが カーボン粒子を捉えているところを観察したSEM 画像が図 4 である。䇴表面に形成される $\mathrm{Al}_{4} \mathrm{C}_{3}$ 結晶化合物はウイスカ状 であるとは限らない。図5は,「トーヤルカーボ®」表面を二 次電子像と反射電子像で観察した写真である。黒く球状に見 えるのはカーボン粒子であり，その隙間部に白い粒子状のも のが凝集しているように見えるのが $\mathrm{Al}_{4} \mathrm{C}_{3}$ 結晶化合物であ る。この結果から $\mathrm{Al}_{4} \mathrm{C}_{3}$ 結晶化合物の形態は, ウイスカ状だ けではなくいろいろな形態で存在することがわかる。これ は，アルミニウム䇴圧延時に発生する箔の表面凹凸や䇴表層 
の酸化皮膜の欠陥，さらには箔表面に存在する圧延油由来の 炭化物の存在などが $\mathrm{Al}_{4} \mathrm{C}_{3}$ 結晶化合物の存在形態に大きく影 響を及ぼすためと考えられる。

\section{2 アルミニウム箔の影響}

使用するアルミニウム䇴の純度が $\mathrm{Al}_{4} \mathrm{C}_{3}$ の生成に影響を及 ぼすことがわかっている2)。表 1 に示す純度の異なるアルミ 二ウム箔を炭化水素の雲囲気の中で加熱し，箔表面に生成し

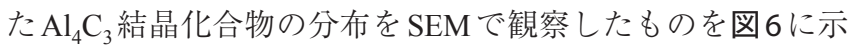
す。

表 1 材質とアルミニウム純度の関係

\begin{tabular}{l|c|c}
\hline \hline & 材質 & アルミニウム純度 $(\%)$ \\
\hline No. 1 & 1N99 & 99.99 \\
No. 2 & 1N90 & 99.98 \\
No. 3 & 1085 & 99.85 \\
No. 4 & 1N30 & 99.30 \\
\hline
\end{tabular}

$1 \mathrm{~N} 30$ 材では，アルミニウム雗表面に $\mathrm{Al}_{4} \mathrm{C}_{3}$ 結晶化合物が部 分的に偏在するのに対し，1085材では分布領域が拡がって いることが確認できる。さらに1N90，1N99材ではアルミニ ウム箔表面を $\mathrm{Al}_{4} \mathrm{C}_{3}$ 結晶化合物がほぼ覆い尽す状態となって いることがわかる。

また，アルミニウム基材として1085材と 1N90材を用いて 図1の「トーヤルカーボ®」の製造工程に従い, 同じ製造条 件の下でカーボン粒子を固定した。その試料をブロムーメ夕 ノール混合溶液に浸漬することで金属アルミニウムを完全に 溶解させ，残ったカーボン粒子層および $\mathrm{Al}_{4} \mathrm{C}_{3}$ 結晶化合物の レプリカを裏面側から SEM 観察を行ったものが図7である。 各材料ともに $\mathrm{Al}_{4} \mathrm{C}_{3}$ 結晶化合物で覆い尽されているが, 1085 材に比べ純度の高い $1 \mathrm{~N} 90$ 材の方が $\mathrm{Al}_{4} \mathrm{C}_{3}$ 結晶化合物のサイ ズが大きいことがわかる。

さらに, $\mathrm{Al}_{4} \mathrm{C}_{3}$ の生成量の違いを明確にするために定量分 析を行った。化学定量分析は, $50 \mu \mathrm{m}$ のアルミニウム箔を

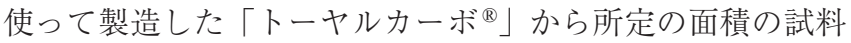
を採取し，苛性ソーダに浸漬して完全に溶解させる。このと
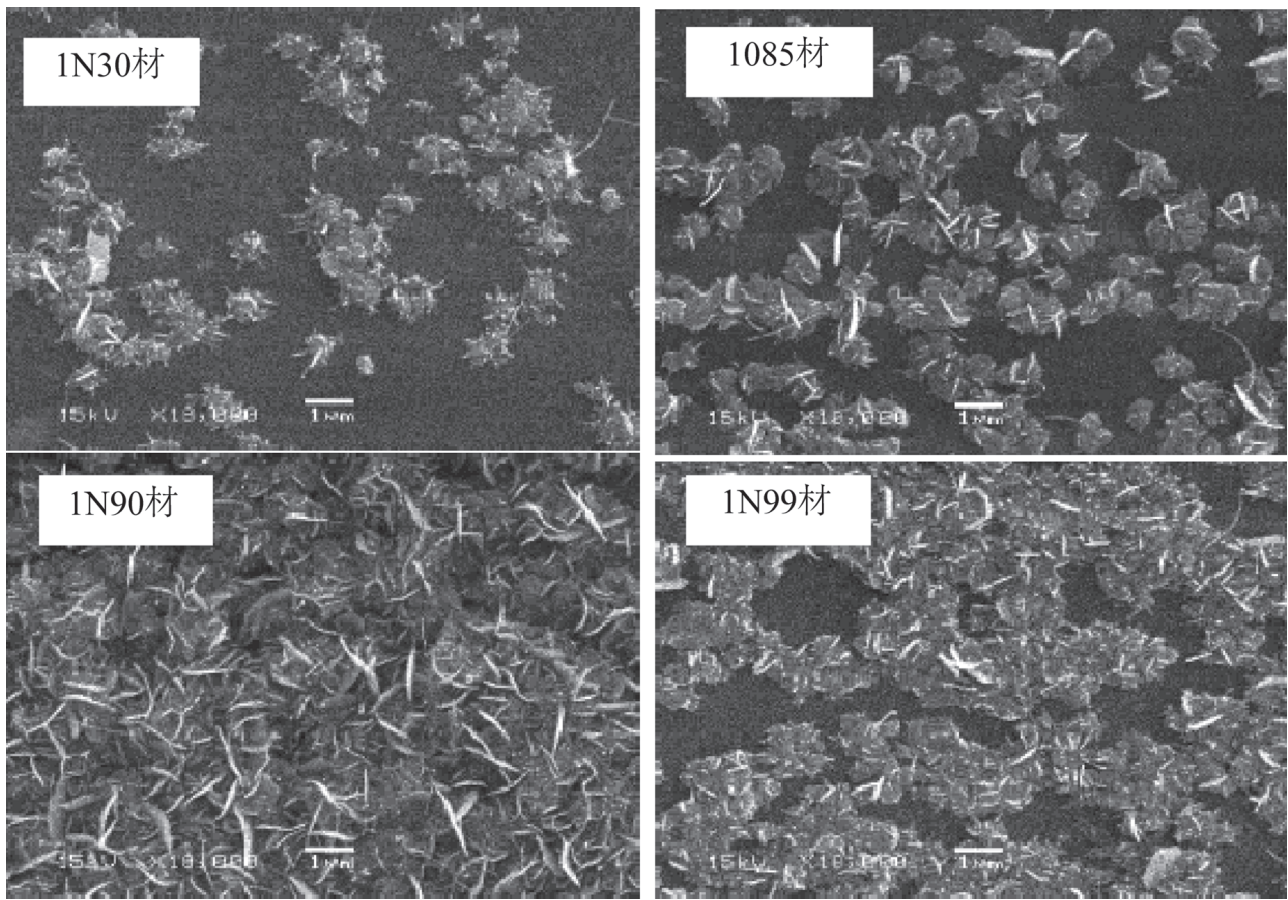

図6 純度の異なる箔表面に形成した $\mathrm{Al}_{4} \mathrm{C}_{3}$ の $\mathrm{SEM}$ 観察
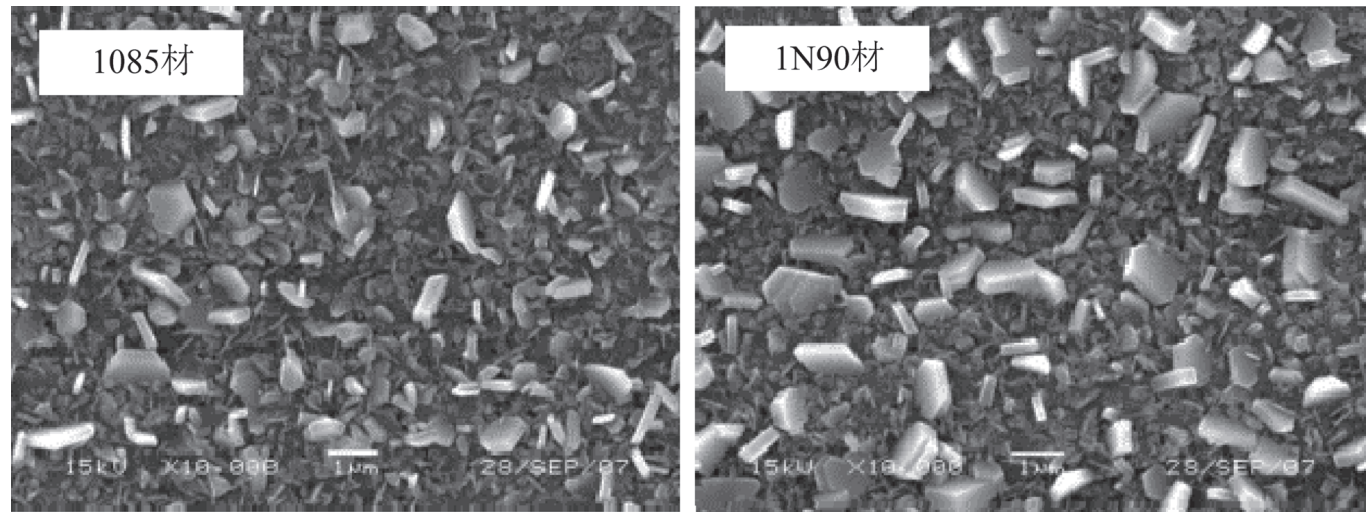

図7 $\mathrm{Al}_{4} \mathrm{C}_{3}$ レプリカ裏面のSEM観察 
表 $2 \mathrm{Al}_{4} \mathrm{C}_{3}$ 量の定量分析結果

\begin{tabular}{c|c}
\hline \hline & $\mathrm{Al}_{4} \mathrm{C}_{3}$ 量 $(\operatorname{mass} \%)$ \\
\hline $1 \mathrm{~N} 99$ 材 & 0.8 \\
$1 \mathrm{~N} 90$ 材 & 0.7 \\
1085 材 & 0.5 \\
\hline
\end{tabular}

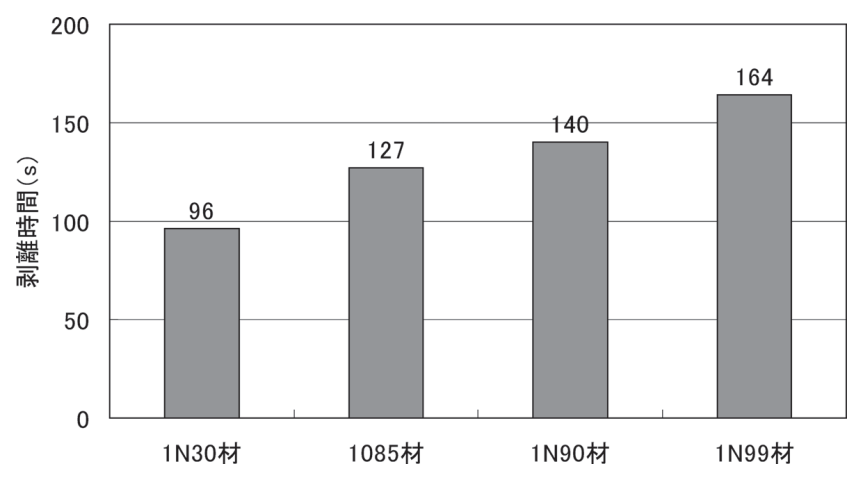

図8 塩酸剥離試験結果

きにアルミニウムから発生した水素ガスと $\mathrm{Al}_{4} \mathrm{C}_{3}$ から発生し たメタンガスを収集し，ガスクロマトグラフィにて定量分析 したガスの比率から重量比を算出したものが表2である。こ の結果からもアルミニウム純度が高いほど $\mathrm{Al}_{4} \mathrm{C}_{3}$ 生成量が多 くなっていることがわかる。これは，アルミニウム純度が低 いとアルミニウム箔内に含まれる不純物が熱拡散により箔表 面に集積し，この不純物の集積層が雲囲気中の炭素成分とア ルミニウムとの化学反応を妨げ，その結果として $\mathrm{Al}_{4} \mathrm{C}_{3}$ の形 成量が少なくなったためと考えられる。

また, $\mathrm{Al}_{4} \mathrm{C}_{3}$ 化合物の生成量とカーボン粒子の固定力の関 係について調査した。純度の異なるアルミニウム筞を用いて 先程と同様に作製した「トーヤルカーボ ${ }^{\circledR} 」 を ， 353 \mathrm{~K} に$ 加 熱した $1 \mathrm{M}$ 塩酸水溶液に浸漬し，アルミニウム箔からカーボ ン粒子が剥れるまでの時間を測定した。その結果を図8に示 す。

アルミニウム箔の純度が高くなることでカーボン粒子が剥 れる時間が長くなっていることから, $\mathrm{Al}_{4} \mathrm{C}_{3}$ の生成量がカー ボン粒子の固定力に影響していることがわかる。

\section{3.「トーヤルカーボ®」の電気化学特性}

\section{1 静電容量}

「トーヤルカーボ®」は，アルミニウム箔の表面にカーボ ン粒子を固定することで表面積を拡大している。つまり，固 定するカーボン粒子のサイズと量を変えることで静電容量を コントロールすることができる。

静電容量の出現を確認するために, カーボン粒子層の厚さ を $1 \sim 4 \mu \mathrm{m} /$ 片面に変化させた「トーヤルカーボ $」$ を作製し, その静電容量を測定した。なお，静電容量の測定は，LCR メータを用いて周波数を $120 \mathrm{~Hz}$ に設定し, $150 \mathrm{~g} / \mathrm{l}$ アジピン酸 アンモニウム水溶液中で対向法で測定した。各試料は測定面 積が $1 \mathrm{~cm} \times 5 \mathrm{~cm}$ になるように旗型に打抜いて測定を行った。

図9は, カーボン粒子層の厚さと静電容量の関係を表した ものである。図中に示した点線は, 現在アルミニウム電解コ ンデンサの院極に使用されている最高容量レベルのエッチド

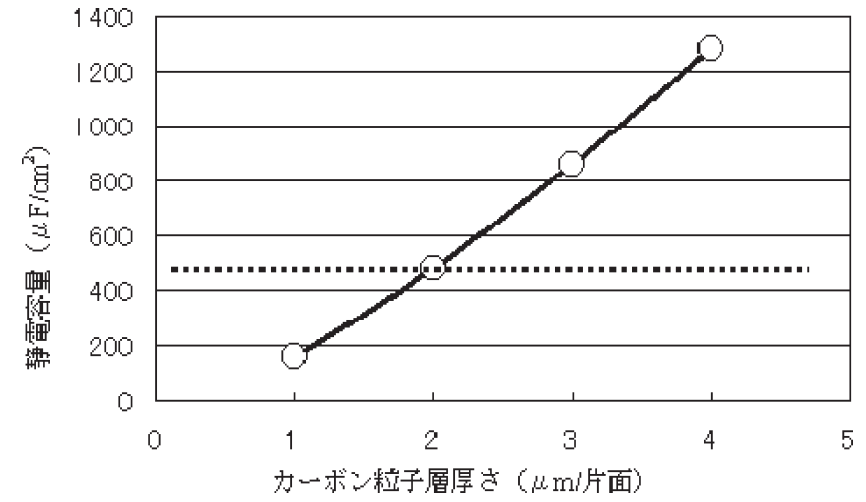

図 9 カーボン粒子層厚さと静電容量值との関係

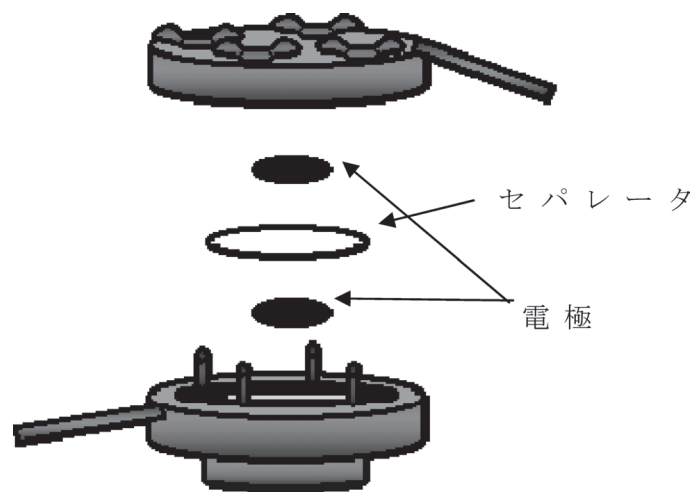

図10ＥDLCセル

箔の静電容量である。「トーヤルカーボ®」の静電容量は $2 \mu \mathrm{m} /$ 片面でほぼ最高容量のエッチド箔と同レベルになり, さらに カーボン粒子層厚さに正比例して増大することがわかる。

\section{2 電気抵抗の測定}

「トーヤルカーボ 」は, カーボン粒子の固定量で表面積 が変化する。一方, 表面抵抗值は表面積の影響を受けるので 単純に材料としての抵抗值を評価することは難しい。

そこで，電気二重層コンデンサ（以下EDLCと記す）の集 電体として用いることで基材としての抵抗值の比較を試み た。EDLCの電極となる集電体は, 一般に用いられている エッチド䇴と, 比較のための 1085 材および「トーヤルカー ボ ${ }^{\circledR}$ を使用し，その上に活物質スラリーとして日立化成工 業(株)製「ヒタゾル GA-1000」を片面に厚さ $50 \mu \mathrm{m}$ （溶媒を乾 燥させた状態）となるように塗布したものを電極とした。な お，電極のサイズは $\phi 12 \mathrm{~mm}$ としたものを 2 枚作製し，電極 が接触しないようにセルロース系セパレータを挟んだ。

電解液は $1.5 \mathrm{M}$ の $\mathrm{TEMABF}_{4} / \mathrm{PC}$ を用い, 図 10 に示す $\mathrm{EDLC}$

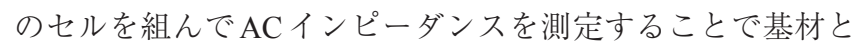
しての抵抗を比較した。

測定は $18 \mathrm{mHz}$ から $20 \mathrm{kHz}$ まで連続的に周波数を变更し コール・コールプロットにて表示した。

その結果を図 11 に示す。電極の抵抗成分として表される 円弧の直径は「トーヤルカーボ®」が最も小さく, 電荷の移 動がスムーズに行われていることがわかる。このことから， アルミニウム箔の表面には自然酸化皮膜が存在し, その皮膜 が抵抗成分となって電極の内部抵抗となって現れるが, 「トーヤルカーボ ${ }^{\circledR}$ は炭化水素の雲囲気で加熱されること 
により,アルミニウム酸化皮膜の成長が抑制された状態で $\mathrm{Al}_{4} \mathrm{C}_{3}$ 結晶化合物が形成されることで，導電性に優れた構造 となっているものと考えられる ${ }^{3)} 。$

また，同じEDLCセルを用いてコンデンサとしての充放電

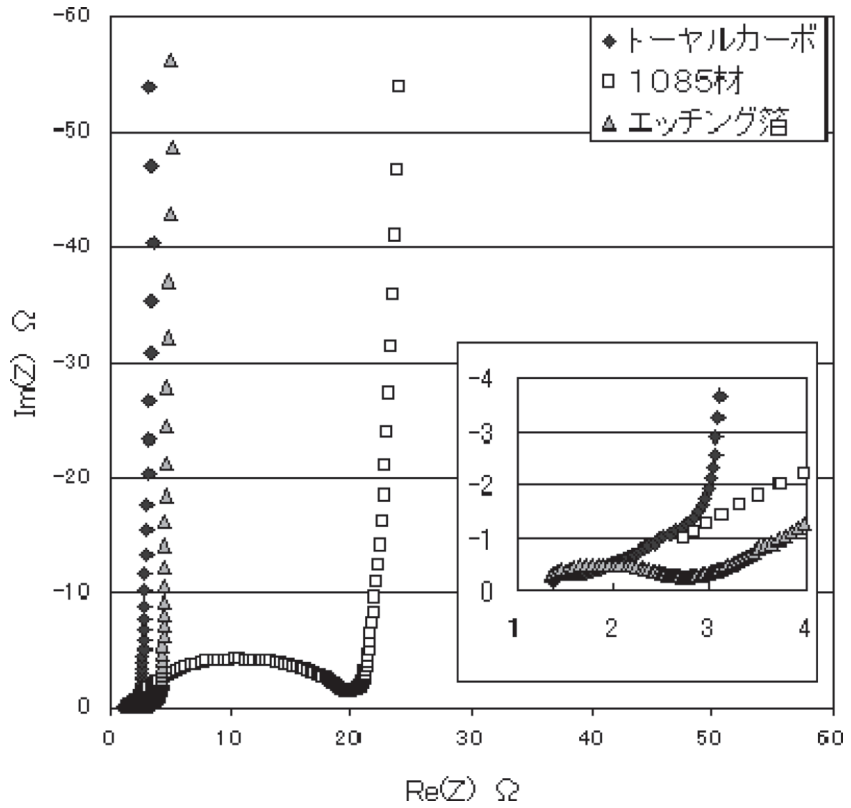

図11 ACインピーダンス測定結果
特性を測定した結果を図12に示す。

充放電の測定条件は, $5 \mathrm{~mA}$ の定電流で $1 \mathrm{~V}$ から $2.5 \mathrm{~V}$ まで 充電後に, $10 \mathrm{~mA}$ の定電流で $2.5 \mathrm{~V}$ から $1 \mathrm{~V}$ まで放電を行うこ とにより測定した。表3は，その放電時に電極の抵抗成分と なって現れるIRドロップの值から電極の抵抗值を算出した ものである。その測定結果も「トーヤルカーボ®」が最も電 気抵抗が少なくなっていることがわかる。

このような内部抵抗の低い基材を電極に使うことで、コン デンサや電池のESR（等価直列抵抗）を下げることが可能と なり電気容量の減少を抑えられ, 電気抵抗から生まれる発熱 なども低減することが可能となる。

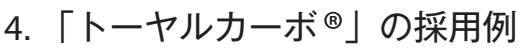

\section{1 機能性固体高分子コンデンサ}

「トーヤルカーボ ${ }^{\circledR} は$ は, 電子伝導性に優れていることか ら電子部品の電極に適した材料であることがわかる。この特 徵を活かして採用されている商品が, 機能性固体高分子コン

表 3 IRドロップから算出した抵抗值

\begin{tabular}{c|c}
\hline \hline 基材 & 抵抗值 $(\Omega)$ \\
\hline 1085 材 & 12.4 \\
エッチド筞 & 3.9 \\
トーナルカーボ® & 2.3 \\
\hline
\end{tabular}

1085材
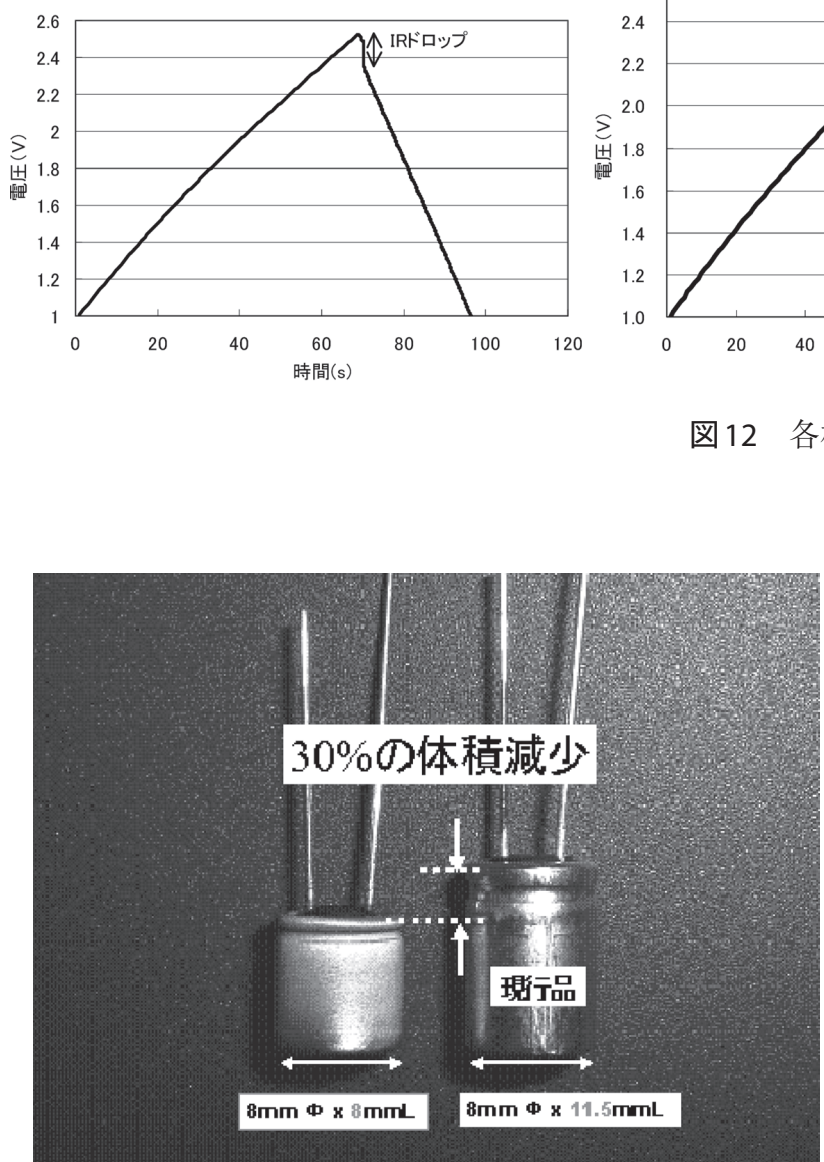

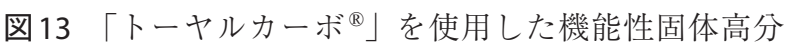
子コンデンサと現行品との比較
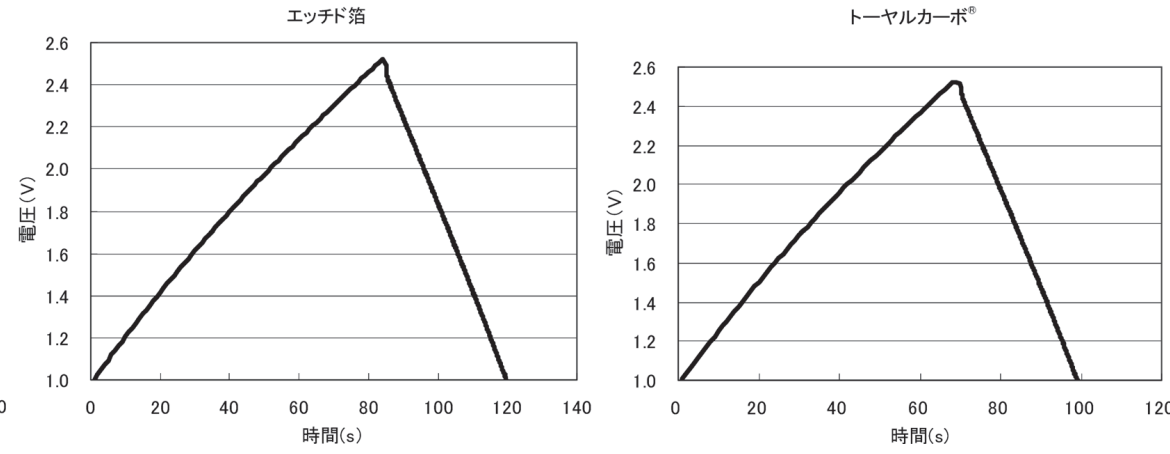

図 12 各材料の充放電特性

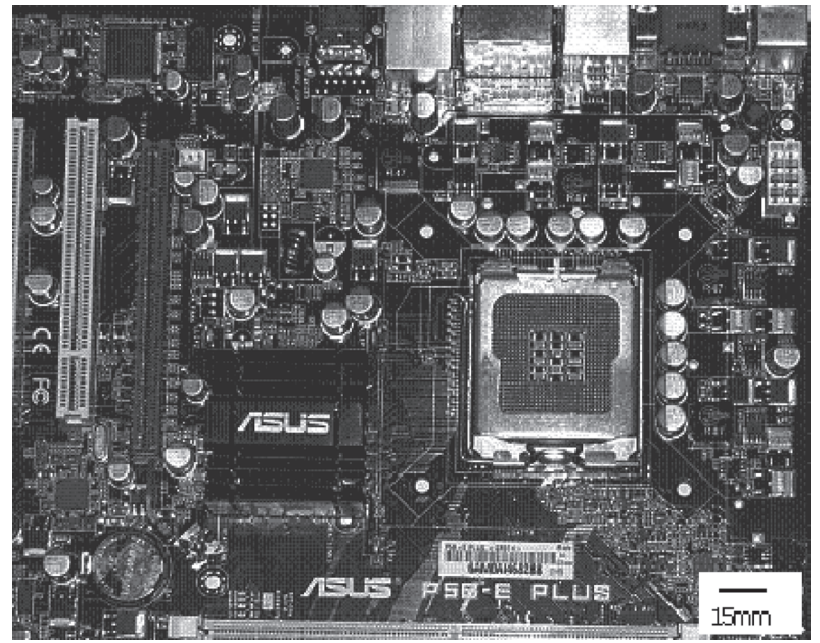

図14すべて機能性固体高分子コンデンサに置換わっ たPC用マザーボード 


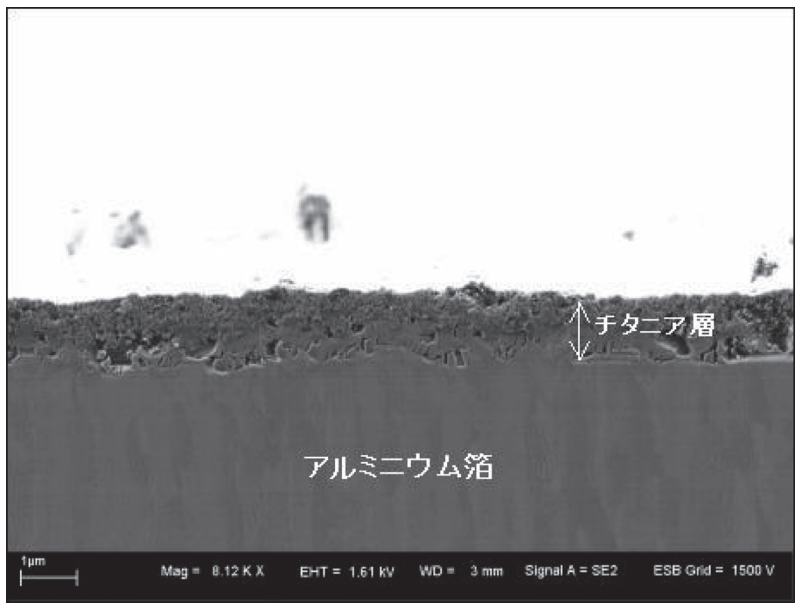

図15「トーヤルチタン ${ }^{\circledR}$ の断面写真

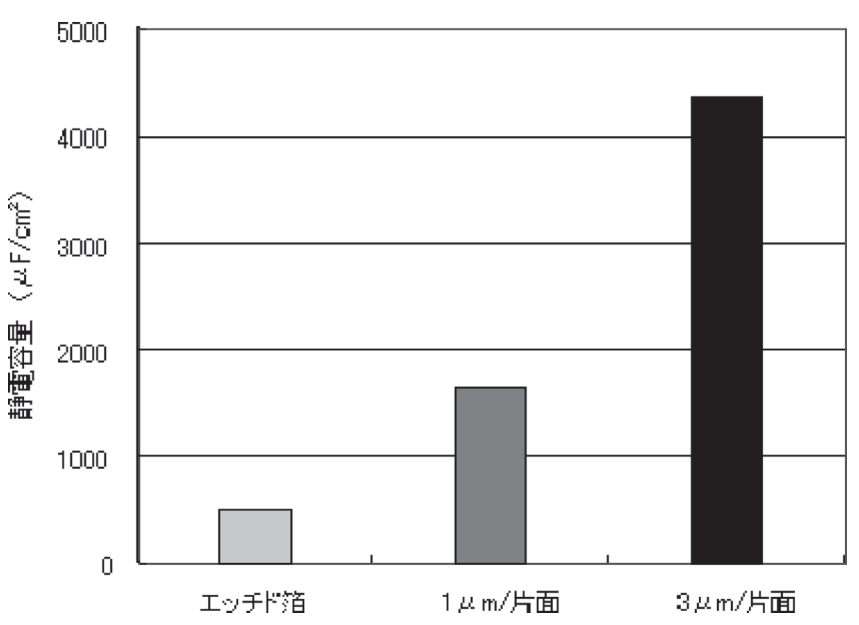

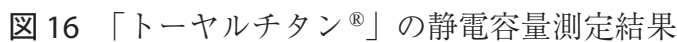

デンサである。従来このコンデンサの院極にはアルミニウム 電解コンデンサと同様にエッチド箔が採用されていたが, 「トーヤルカーボ®」に置換えることでESRの低減および静 電容量の増大が可能となった。実際に「トーヤルカーボ を採用したコンデンサの比較を図 13 に示す。「トーヤルカー ボ®」を採用することでコンデンサの静電容量が向上し，使 用する電極面積が少なくなる。その結果，体積で $30 \%$ も小 型化が可能となった。このようなコンデンサは，進化し続け るコンピュータのCPU周辺に最も多く採用されている。図 14 は, デスクトップ型パーソナルコンピュータのマザーボー ドに搭載されているアルミニウム電解コンデンサをすべて機 能性固体高分子コンデンサに置換えたものである。このよう にパーソナルコンピュータの高性能化・小型化・高寿命に貢 献している。

また，今日では作動電圧の高い機能性固体高分子コンデン サも開発され，液晶テレビ，LED照明機器など，ますます 採用が拡大している。

\section{2 電気二重層コンデンサ（EDLC）}

EDLCの歴史も古く, 夜間に点灯する道路標識や道路鋲な どの電源に太陽電池と組合せた製品として採用されてきた。 また近年では，風力発電の平準化用あるいは自動車，電車な どの運動エネルギーから生まれる回生エネルギーの蓄電デバ イスとして採用され，さらに大型のものでは工場における瞬

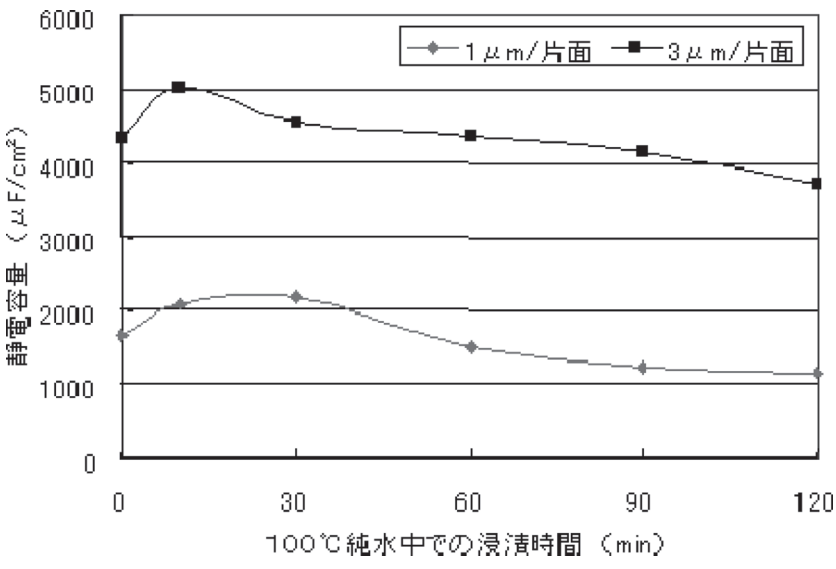

図17「トーヤルチタン」の耐水性評価

時電圧低下補償装置の電源としても採用されている。

特に, 最近では小型携帯機器の発展とともに二次電池への 負荷が大きくなっている。つまり, 電子機器の機能が高まれ ば，使用する電気量の変動が大きくなるので二次電池の消耗 が激しくなる。その平準化用としてもEDLCの需要が高まり つつある。EDLCの電極の基材として「トーヤルカーボ ${ }^{\circledR}$ を採用することで低ESR化による発熱量の低減, 静電容量 の低下抑制や長寿命化などコンデンサとしての性能が大きく 向上したと高い評価を得ていることから，用途の拡大に向け さらなる特性向上に取組んでいる。

\section{5. 今後の発展}

「トーヤルカーボ®」は, 有機バインダを使用せずカーボ ン粒子をアルミニウム箔に固定した商品である。したがっ て，固定する材料はカーボン粒子に限らず，その必要な特性 に応じた材料を固定することができる。例えば，微細なチ夕 ニア粒子を固定し，表面積の拡大効果を活かした商品として 「トーヤルチタン®」を開発した。図15にそのSEMによる断 面写真を示す。この写真からもチタニアの微粒子がアルミニ ウム箔表面に積層されていることがわかる。この商品は, チ タニアの安定性と粒子の緻密な積層によりこれまでにない大 きな表面積を備えることができた電極である。これは, 炭化 水素の雲囲気でチタニア粒子を加熱処理することで, その表 層が還元され導体化したことでその特性が得られた。図 16 は,「トーヤルチタン ${ }^{\circledR} 」 の$ 静電容量の測定結果である。静 電容量がチタニア粒子層の厚さに正比例していることは 「トーヤルカーボ®」と同様であるがその数值は桁違いに大 きいことがわかる。

また, 図17に示すように電極を沸騰水に浸漬し, その静 電容量の変化を調査した。一般的にエッチド箔を沸騰水に浸 漬した場合，水酸化皮膜を形成することで容量低下を引起し 数分で静電容量が半減する。それに比べ「トーヤルチタン」 ${ }^{\circledR} 」$ はアルミニウム箔表面を緻密に微粒子で覆っていることで水 和反応を抑制していることがわかる。この電極を液系アルミ ニウム電解コンデンサの㓌極として用いることで, 経時安定 性に優れ小型化されたコンデンサとして商品化されている。

また，4.2節で述べたEDLC電極への応用として，アルミ ニウム箔に直接活性炭を $\mathrm{Al}_{4} \mathrm{C}_{3}$ で固定した電極を開発中であ る。この電極も活性炭の固定に有機高分子を使っていないの 
で，低ESRに加えて耐熱性に優れた電極であり，今後ユー ザからの高い要求に応える電極として開発を進めている。

\section{6. まと め}

アルミニウム箔を炭化水素の雲囲気中で $873 \mathrm{~K}$ 以上の温度 に加熱することで，アルミニウム䇴の表層部に $\mathrm{Al}_{4} \mathrm{C}_{3}$ を主成 分とする板状の結晶およびウイスカが生成することを発見し た。その結晶化合物の生成を利用してアルミニウム箔表面に カーボン粒子を固定することに成功した。

そのカーボン粒子を固定したアルミニウム箔は, 低抵抗, 表面積の拡大など非常に優れた電気特性を有しており，量産 性においても安定した品質が認められ，今日も発展し続ける 電子部品の電極として広く採用されるに至った。

当社が開発した技術は，アルミニウム箔への粒子の固定技 術であり，固定する材料はその目的および用途に応じて自由
に設計することができると考えている。今後も求められる特 性に応じて材料を見極め, 電子部品に限らず世の中に貢献で きる材料の開発を目指していきたい。

\section{7. 謝辞}

「トーヤルカーボ®」の開発において, $\mathrm{Al}_{4} \mathrm{C}_{3}$ 結晶化合物の 発見当時から製品開発，そして商品化に至るまで懇切丁寧に ご指導を賜った京都大学名誉教授 村上陽太郎先生に感謝の 意を表します。

参 考 文 献

1）呂 明哲，足高善也：軽金属 $60(2010), 552-558$,

2) 井上英俊 : 電解蓄電器評論, 59 (2008)

3）石川正司, 今井 寞, 井上英俊, 足高善也, 呂 明哲, 多田裕 志：電気化学会2006年春季大会講演概要集, (2006), 274. 